\title{
Effects of ascorbic acid and lighting schedule on tibiotarsus strength and bone characteristics in broilers
}

\author{
HUSEYIN YILDIZ1 ${ }^{1}$ NAZMIYE GUNES ${ }^{1}$, S. SULE GEZEN ${ }^{1}$, RESAT OZCAN ${ }^{1}$, METIN PETEK ${ }^{1}$, \\ BESTAMI YILMAZ ${ }^{2}$ and ILKER ARICAN ${ }^{1}$
}

${ }^{1}$ Uludag University, Görükle-Bursa, Turkey, ${ }^{2}$ Harran University, Şanlıurfa, Turkey

\section{Abstract}

This study was conducted to determine the effects of two lighting programs (continuous program; $24 \mathrm{~h}$ lighting or intermittent; $12 \mathrm{~h}$ daylight followed by three cycles of $1 \mathrm{~h}$ lighting and $3 \mathrm{~h}$ dark program during the night period) and three different ascorbic acid (AA) supplementations $(0,200$ and $400 \mathrm{mg} / \mathrm{l}$, added to water) on some serum parameters, ash content and mechanical properties of tibiotarsus. For this purpose one-day-old male commercial (Ross $\mathrm{PM}_{3}$ ) broiler chicks $(n=600)$ were divided into 6 treatment groups $(2 \times 3)$ with random replicates (4 replicates per treatment). At the end of 6 weeks, intermittent lighting program negatively influenced serum alkaline phosphatase (ALP) and calcium (Ca) levels $(P<0.001)$ while continuous lighting program had positive influence on bone ash, $\mathrm{Ca}$ and phosphorus $(\mathrm{P})$ content $(P<0.001)$. The AA addition decreased serum inorganic phosphorus $(\mathrm{Pi})$ level and positively affected bone chemical characteristics $(P<0.001)$. On the mid-section of the bone, although intermittent lighting had positive effect on bone mechanical parameters $(P<0.001)$, no remarkable effect was observed by AA supplementation. The results of the present study suggest that interaction of intermittent lighting and AA supplementation $(200 \mathrm{mg} / \mathrm{l})$ may have positive effect on chemical composition and mechanical characteristics of bone in broilers.

Keywords: broiler, lighting, ascorbic acid, tibiotarsus, ash, breaking force

\section{Zusammenfassung}

\section{Einfluss von Ascorbinsäure und Beleuchtungsprogrammen auf die Tibiotarsusfestigkeit und weitere Knochenmerkmale bei Broilern}

Bei 600 einen Tag alten männlichen Ross $\mathrm{PM}_{3}$ Broilerküken kamen in 6 Behandlungsgruppen $(2 \times 3)$ und jeweils vier Wiederholungen pro Behandlung folgende Behandlungen zur Anwendung: Ein Beleuchtungsprogramm mit $24 \mathrm{~h}$ kontinuierlicher Beleuchtung sowie Intervallprogramm mit $12 \mathrm{~h}$ Tageslicht gefolgt von 3 Zyklen d.h. $1 \mathrm{~h}$ Beleuchtung und $3 \mathrm{~h}$ Dunkelperiode. Weiterhin erfolgte eine unterschiedliche Ascorbinsäuregabe (AA) von 0, 200 bzw. $400 \mathrm{mg} / \mathrm{l}$ in das Trinkwasser. Beobachtet wurden bei diesen Versuchsvarianten die Auswirkungen auf Serumparameter, Aschegehalt und mechanische Eigenschaften des Tibiotarsus. Am Ende der 6. Woche wurde festgestellt, dass beim Intervalllichtprogramm die alkalische Phosphatase und die Kalziumkonzentration signifikant negativ beeinflusst wurden, während beim kontinuierlichen Programm ein 
signifikant positiver Einfluss auf den Asche-, Kalzium und Phosphatgehalt nachgewiesen wurde. Ein AA-Zusatz reduzierte die anorganische Phosphorkonzentration und übte einen signifikant positiven Einfluss auf die chemischen Knocheneigenschaften aus. Das Intervallprogramm ergab mehr als die AA-Zugabe im mittleren Teil des Tibiotarsus einen positiven Einfluss auf die mechanischen Knochenparameter. Insgesamt fanden sich bei den Varianten Intervallprogramm und AA-Zugabe von $200 \mathrm{mg} / \mathrm{l}$ im Trinkwasser die besten Wirkungen hinsichtlich chemischer und mechanischer Knocheneigenschaften.

Schlüsselwörter: Broilerküken, Beleuchtungsprogramm, Ascorbinsäure, Tibiotarsus, Asche, Bruchfestigkeit

\section{Introduction}

Commercial broilers are economic agricultural field production units in which the objective is to maximize field performance (ANDRASSY-BAKA et al. 2003). But, broilers are under the stress due to faster growth rate and negative environmental conditions (MCCORKLE and GLICK 1980). Today's broilers reach their slaughter weight in around 41 days, but the supporting structure of legs fail to keep pace with the rapid growth rate, and can buckle under the strain of supporting the overgrown body (SANOTRA et al. 2001). As a result, market age poultry often suffer from lameness and bone deformities, which can cause bone breakage during catching and transportation and which create problems during processing (KNOWLES and WILKINS 1998).

Bone is a dynamic tissue influenced by physical, physiological and nutritional activities (RATH et al. 2000). Nutrient requirements, including mineral requirements, change with age. Bone breakage in chicken is due to weak bones as a result of $\mathrm{Ca}$ depletion. The $\mathrm{Ca}$ and $\mathrm{P}$ are primary inorganic nutrients in the bone that may be important for bone strength (KNOWLES and WILKINS 1998). In recent years, there has been increasing interest over the relationship of feeding with bone strength and skeletal disorders in broilers (FLEMING et al. 1998, EDWARDS 2000, AFSHARMANESH and POURREZA 2005). Field data and test results show that supplementation with $A A$ is necessary for decreasing the incidence of bone breaking strength (DOAN and GIANG 1998). The AA is an activator of enzyme 25-hydroxyl vitamin D3-1 hydroxylase, which is required for the regulation of $\mathrm{Ca}$ absorption and excretion. Thus, $\mathrm{AA}$ nutrition influences $\mathrm{Ca}$ and $\mathrm{P}$ metabolism in young chicks. Birds are normally able to synthesize adequate amounts of AA however, there are many indications showing that they can not produce enough AA for their metabolic needs (COATES 1984). KUTLU and FORBES (1993) reported that the amount of AA to be added into feed for broiler health was not clear.

At the same time, bone characteristics would also be also affected by lighting program (ZUBAIR and LEESON 1996, LASTER et al. 1999). The intermittent lighting programs are better than continuous ones for broiler leg disorders (PETEK et al. 2005). Increased light programs may reduce the incidence of skeletal disease. Nevertheless, the weight and strength of tibiotarsus would not be significantly affected by the intermittent lighting schedule (INGRAM et al. 2000).

There is increased interest from the poultry industry and scientific community regarding to the bone quality and welfare of birds. The objective of the present study was 
to determine comparatively serum and bone characteristics and mechanical properties of tibiotarsus in broilers that were subjected to continuous or intermittent lighting programs in association with supplementation of different ration of AA in drinking water.

\section{Material and methods}

The experimental procedures employed in this study were in accordance with the principles and guidelines set out by the Committee of Faculty of Veterinary Medicine on Animal Care. This experiment was conducted at the Livestock Research Centre at the Faculty of Veterinary Medicine in Bursa, Turkey in the month of April. The daylight was nearly $12 \mathrm{~h}$ at this period in the region. Day-old male chicks ( $n=600$, Ross $\mathrm{PM}_{3}$ ) obtained from a commercial hatchery were reared in two windowed houses with usual brooding techniques until 6 weeks of age.

\section{Experimental methods}

The chicks were randomly divided into 6 treatment groups (100 chicks per treatment) according to the lighting programs (continuous or intermittent) and AA supplementation $(0,200$ and $400 \mathrm{mg} / \mathrm{l}$, added into the drinking water). In the continuous lighting program the birds received $24 \mathrm{~h}$ light per day whereas in the intermittent group the birds were subjected to $12 \mathrm{~h}$ light during daytime and $1 \mathrm{~h}$ light; $3 \mathrm{~h}$ dark $\times 3$ cycles during nighttime. 4 replicates (each containing 25 animals that were housed in $1 \times 3 \mathrm{~m}$ floor pens) were used for each of treatment group.

\section{Bird husbandry}

Newly hatched chicks in all treatments were reared at the same environmental conditions (floor space, bird density, feeder and drinker space) in deep litter pens. Birds in all trials consumed commercial maize based on; broiler starter ration from 1 to 21 days of age ( $M E=12.50 \mathrm{MJ} / \mathrm{kg}, 220 \mathrm{~g} / \mathrm{kg}$ total protein), broiler grower ration from 22 to 35 days of age $(M E=12.70 \mathrm{MJ} / \mathrm{kg}, 200 \mathrm{~g} / \mathrm{kg}$ total protein) and finally a broiler finisher ration from 36 to 42 days ( $\mathrm{ME}=12.92 \mathrm{MJ} / \mathrm{kg}, 180 \mathrm{~g} / \mathrm{kg}$ total protein). Within each pen, water was provided via a hanging automatic bell drinker and feed was provided ad libitum via a hanging tube feeder. Broilers received natural day light during daytime and artificial light (continuous or intermittent) during the nighttime. For intermittent lighting an automatic timer was used. AA was supplemented in powder form into the drinking water $(0,200,400 \mathrm{mg} / \mathrm{l}$ water) during whole life cycle of animals.

\section{Assessment of traits}

The birds in each pen were weighed individually at 42nd day and the blood samples were taken from neck vein by puncture and drawn into vacutainer tubes. The blood samples were then centrifuged at $3000 \mathrm{rpm}$ for $10 \mathrm{~min}$. Serum Ca (TECO Diagnostics kit, Cat no: $\mathrm{C}$ 503-480, USA) and Pi (TECO Diagnostics kit, Cat. No 1515-480, USA) levels were immediately measured by means of commercial kits. Serum samples were then stored at $-20^{\circ} \mathrm{C}$ for measuring ALP activity (TECO Diagnostics kit, Cat. No A504-150, USA). 
After blood collection, the birds were killed humanely by decapitation (ANONYMUS 2003) and defeathered. The right tibiotarsus was immediately dissected from the surrounding tissues and kept frozen in plastic bags at $-20^{\circ} \mathrm{C}$ until necessary measurements. Frozen tibiotarsuses were later thawed at room temperature for $1 \mathrm{~h}$ (CRENSHAW 1986). Bone weight (Precisa XB 4200C, Zurich, Switzerland) were measured. Physical bone characteristics were determined by three-point bending test commonly used to assess bone strength in poultry (CRENSHAW et al. 1981). Thus, diaphyseal shaft was divided into 3 sections (proximal, mid, and distal) having a thickness of $0.6 \mathrm{~cm}$ by using an Instron Universal Testing Machine (Model 4301, Instron Corp., Canton, MA 02021) fitted with a 5 kN load cell (Figure 1). Bones were placed dorsal side up on support $7 \mathrm{~cm}$ apart. The centre of each bone was aligned with the breaking probe which approached at $25.4 \mathrm{~mm} / \mathrm{min}$. Ultimate bone breaking force (Newtons, N), stress (Megapascals, MPa) and modulus of elasticity (MPa) were determined for each tibiotarsus.
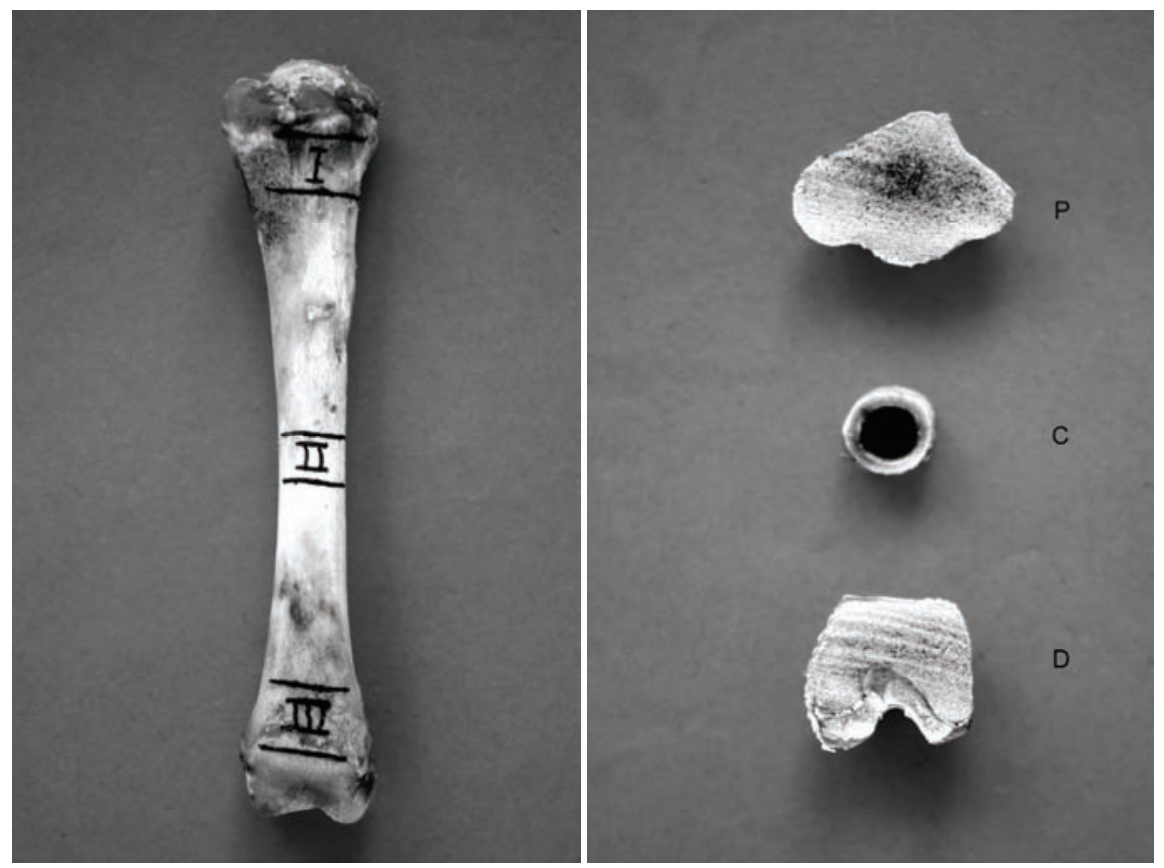

Figure 1

Cross section of the Tibiotarsus, I. section: (P, Proximal section), II. section: (C, mid section), III. section: (D, distal section)

Horizontaler Schnitt des Tibiotarsus, I. Schnitt (P, Proksimalschnitt), II. Schnitt (C, Mittelschnitt), III. Schnitt (D, Distalschnitt)

In order to determine the bone ash, ten left tibiotarsuses from each group were analyzed according to the technique described by Association of Official Agricultural Chemists (1955). The bones were carefully separated from surrounding flesh and cartilage tissues and kept in boiling water to eliminate any resting meat particles. Thereafter, the bones were treated with ethanol and anhydrous ether for $24 \mathrm{~h}$, dried and weighed before replacing at $600^{\circ} \mathrm{C}$ for $6 \mathrm{~h}$. Bone Ca was determined photometrically and P level were determined according to GERICKE and KURMIES (1952). 


\section{Statistical analysis}

Body weight, serum and bone properties of broilers in the groups were analyzed using ANOVA with the general linear model procedure of SPSS computer software 10.00 (SPSS INC. 1999). When differences among the groups were significant, means were separated using Tukey test (SNEDECOR and COCHRAN 1989). Lighting and supplemental AA were the main effects. Results presented in the tables for the serum and bone properties are expressed as mean values $\pm \mathrm{SE}$.

\section{Results}

The main and interactive effects of different lighting and AA supplementation on body and bone weights are presented in Table 1. Data obtained for the animals that were subjected to intermittent lighting was significantly better $(P<0.05)$ than those receiving continuous lighting. AA supplementation and the interactive effect of lighting and $A A$ supplementation had no significant effect on body weight. A significant increase in the weight of tibiotarsus was observed for the AA supplemented groups $(P<0.001)$.

Table 1

The main and interactive effects of lighting and supplemental AA on body and tibiotarsus weight

Die Haupt- und interaktiven Wirkungen von Beleuchtung und ergänzender AA-Gabe auf Körper- und Tibiotarsusgewicht

\begin{tabular}{|c|c|c|c|}
\hline Lighting & $\mathrm{AA}, \mathrm{mg} / \mathrm{l}$ & Body weight, g & Tibiotarsus weight, g \\
\hline \multicolumn{4}{|l|}{ Main effects } \\
\hline Continuous & & $2272.48 \pm 13.30^{b}$ & $12.56 \pm 0.22^{b}$ \\
\hline \multirow[t]{4}{*}{ Intermittent } & & $2317.83 \pm 13.38^{\mathrm{a}}$ & $13.25 \pm 0.36^{\mathrm{a}}$ \\
\hline & 0 & $2295.50 \pm 16.39$ & $11.99 \pm 0.27^{b}$ \\
\hline & 200 & $2307.63 \pm 16.28$ & $13.09 \pm 0.31^{\mathrm{a}}$ \\
\hline & 400 & $2282.34 \pm 16.35$ & $13.64 \pm 0.46^{\mathrm{a}}$ \\
\hline \multicolumn{4}{|l|}{ Interactive Effects } \\
\hline Continuous & 0 & $2278.83 \pm 23.18$ & $12.02 \pm 0.39$ \\
\hline Continuous & 200 & $2267.86 \pm 22.85$ & $12.34 \pm 0.56$ \\
\hline Continuous & 400 & $2270.69 \pm 23.07$ & $13.32 \pm 0.84$ \\
\hline Intermittent & 0 & $2312.10 \pm 23.18$ & $11.96 \pm 0.67$ \\
\hline Intermittent & 200 & $2347.40 \pm 23.18$ & $13.84 \pm 0.44$ \\
\hline Intermittent & 400 & $2293.98 \pm 23.18$ & $13.95 \pm 0.31$ \\
\hline \multicolumn{4}{|l|}{ ANOVA } \\
\hline Lighting & & * & * \\
\hline $\mathrm{AA}, \mathrm{mg} / \mathrm{l}$ & & ns & *** \\
\hline Lighting $\times A A, m g / l$ & & ns & ns \\
\hline
\end{tabular}

Data related to the main and interactive effects of different lighting and $A A$ supplementation on some serum and bone parameters are presented in Table 2 and 3, respectively.

Serum ALP and $C a$, and serum Pi levels were negatively influenced $(P<0.001)$ by intermittent lighting and AA supplementation respectively. The interaction of both main factor had influence on the serum ALP level $(P<0.001)$. The bone ash, $C a$ and $P$ of the group of animals that were subjected to the continuous lighting program were 
significantly important $(P<0.001)$. Similarly, bone ash, $\mathrm{Ca}$ and $\mathrm{P}$ content of the group of animals was increased by the gradually augmented AA level. Interaction of lighting and AA supplementation had also influence on the bone ash and $C$ a content $(P<0.001)$.

Table 2

The main and interactive effects of lighting and supplemental AA on some serum parameters

Die Haupt- und interaktiven Wirkungen von Beleuchtung und AA-Supplementation auf einige Serumparameter (mean SEM)

\begin{tabular}{|c|c|c|c|c|}
\hline Lighting & $\mathrm{AA}, \mathrm{mg} / \mathrm{l}$ & ALP, IU & $\mathrm{Ca}, \mathrm{mg} / \mathrm{dl}$ & $\mathrm{Pi}, \mathrm{mg} / \mathrm{dl}$ \\
\hline \multicolumn{5}{|l|}{ Main Effects } \\
\hline Continuous & & $112.44 \pm 5.32^{\mathrm{a}}$ & $8.74 \pm 0.09^{\mathrm{a}}$ & $7.46 \pm 0.18$ \\
\hline \multirow[t]{4}{*}{ Intermittent } & & $95.33 \pm 3.81^{b}$ & $8.29 \pm 0.11^{b}$ & $7.81 \pm 0.20$ \\
\hline & 0 & $101.94 \pm 4.57$ & $8.57 \pm 0.13$ & $8.41 \pm 0.27^{\mathrm{a}}$ \\
\hline & 200 & $105.82 \pm 7.20$ & $8.29 \pm 0.15$ & $7.07 \pm 0.23^{b}$ \\
\hline & 400 & $103.88 \pm 5.48$ & $8.68 \pm 0.11$ & $7.43 \pm 0.14^{b}$ \\
\hline \multicolumn{5}{|l|}{ Interactive Effects } \\
\hline Continuous & 0 & $99.24 \pm 7.18$ & $8.63 \pm 0.17$ & $8.38 \pm 0.33$ \\
\hline Continuous & 200 & $128.99 \pm 10.51$ & $8.71 \pm 0.19$ & $6.89 \pm 0.31$ \\
\hline Continuous & 400 & $109.09 \pm 8.84$ & $8.88 \pm 0.12$ & $7.11 \pm 0.16$ \\
\hline Intermittent & 0 & $104.65 \pm 5.80$ & $8.51 \pm 0.19$ & $8.43 \pm 0.44$ \\
\hline Intermittent & 200 & $82.66 \pm 6.76$ & $7.88 \pm 0.21$ & $7.25 \pm 0.35$ \\
\hline Intermittent & 400 & $98.68 \pm 6.52$ & $8.47 \pm 0.17$ & $7.76 \pm 0.21$ \\
\hline \multicolumn{5}{|l|}{ ANOVA } \\
\hline Lighting & & $* * *$ & $* * *$ & ns \\
\hline $\mathrm{AA}, \mathrm{mg} / \mathrm{l}$ & & ns & ns & $* * *$ \\
\hline Lighting $\times A A, m g / l$ & & $* * *$ & ns & ns \\
\hline
\end{tabular}

Table 3

The main and interactive effects of lighting and supplemental AA on tibiotarsus bone properties Die Haupt- und interaktiven Wirkungen von Beleuchtung und AA-Supplementation auf Tibiotarsuseigenschaften (mean SEM)

\begin{tabular}{|c|c|c|c|c|}
\hline Lighting & $\mathrm{AA}, \mathrm{mg} / \mathrm{l}$ & Bone ash, $\%$ & Bone $\mathrm{Ca}, \%$ ash & Bone $\mathrm{P}, \%$ ash \\
\hline \multicolumn{5}{|l|}{ Main Effects } \\
\hline Continuous & & $64.32 \pm 0.39^{a}$ & $17.69 \pm 0.188^{a}$ & $11.40 \pm 0.088^{\mathrm{a}}$ \\
\hline \multirow[t]{4}{*}{ Intermittent } & & $62.59 \pm 0.86^{\mathrm{b}}$ & $16.52 \pm 0.561^{b}$ & $11.21 \pm 0.423^{b}$ \\
\hline & 0 & $61.98 \pm 0.41^{\mathrm{b}}$ & $16.16 \pm 0.230^{b}$ & $11.12 \pm 0.107^{b}$ \\
\hline & 200 & $64.14 \pm 0.76^{\mathrm{a}}$ & $17.69 \pm 0.451^{\mathrm{a}}$ & $11.32 \pm 0.254^{\mathrm{ab}}$ \\
\hline & 400 & $64.25 \pm 0.14^{\mathrm{a}}$ & $17.47 \pm 0.769^{a}$ & $11.49 \pm 0.563^{\mathrm{a}}$ \\
\hline \multicolumn{5}{|l|}{ Interactive Effects } \\
\hline Continuous & 0 & $65.40 \pm 0.55$ & $17.15 \pm 0.056$ & $11.53 \pm 0.264$ \\
\hline Continuous & 200 & $62.78 \pm 0.69$ & $18.00 \pm 0.159$ & $10.91 \pm 0.339$ \\
\hline Continuous & 400 & $64.79 \pm 0.18$ & $17.83 \pm 0.334$ & $11.75 \pm 0.025$ \\
\hline Intermittent & 0 & $58.56 \pm 0.58$ & $15.08 \pm 0.325$ & $10.72 \pm 0.152$ \\
\hline Intermittent & 200 & $65.61 \pm 0.24$ & $17.39 \pm 0.366$ & $11.70 \pm 0.566$ \\
\hline Intermittent & 400 & $63.72 \pm 0.52$ & $17.11 \pm 0.961$ & $11.22 \pm 0.581$ \\
\hline \multicolumn{5}{|l|}{ ANOVA } \\
\hline Lighting & & $* * *$ & $* * *$ & $* * *$ \\
\hline $\mathrm{AA}, \mathrm{mg} /$ & & $* * *$ & $* * *$ & $* * *$ \\
\hline Lighting $\times \mathrm{AA}, \mathrm{mg} / \mathrm{l}$ & & $* * *$ & $* * *$ & ns \\
\hline
\end{tabular}


The effects of lighting and AA supplementation and their interaction on mechanical characteristics of proximal, mid and distal section of tibiotarsus are presented in Table 4, 5, 6 .

Table 4

The main and interactive effects of lighting and supplemental AA on mechanical characteristics of proximal section of tibiotarsus

Die Haupt- und interaktiven Wirkungen von Beleuchtung und AA-Supplementation auf mechanische Merkmale des proximalen Abschnitts von Tibiotarsus (mean SEA

\begin{tabular}{|c|c|c|c|c|}
\hline Lighting & $\mathrm{AA}, \mathrm{mg} / \mathrm{l}$ & Stress, MPa & Modulus of elasticity, MPa & Breaking force, $\mathrm{N}$ \\
\hline \multicolumn{5}{|l|}{ Main Effects } \\
\hline Continuous & & $9.74 \pm 0.39$ & $67.78 \pm 3.44$ & $394.72 \pm 9.34$ \\
\hline \multirow[t]{4}{*}{ Intermittent } & & $10.36 \pm 0.61$ & $62.11 \pm 3.02$ & $384.41 \pm 9.57$ \\
\hline & 0 & $11.09 \pm 0.67^{a}$ & $70.43 \pm 4.44$ & $415.40 \pm 11.04^{a}$ \\
\hline & 200 & $9.52 \pm 0.97^{b}$ & $64.96 \pm 4.95$ & $371.31 \pm 11.77^{b}$ \\
\hline & 400 & $9.53 \pm 0.18^{b}$ & $59.44 \pm 4.23$ & $382.00 \pm 11.15^{b}$ \\
\hline \multicolumn{5}{|l|}{ Interactive Effects } \\
\hline Continuous & 0 & $9.98 \pm 0.53$ & $70.60 \pm 5.97$ & $410.20 \pm 16.15$ \\
\hline Continuous & 200 & $8.81 \pm 0.74$ & $64.66 \pm 5.03$ & $352.12 \pm 16.17$ \\
\hline Continuous & 400 & $10.43 \pm 0.17$ & $68.06 \pm 5.54$ & $421.85 \pm 16.53$ \\
\hline Intermittent & 0 & $12.20 \pm 0.26$ & $70.26 \pm 5.63$ & $420.60 \pm 16.82$ \\
\hline Intermittent & 200 & $10.23 \pm 0.94$ & $65.25 \pm 5.27$ & $390.50 \pm 16.75$ \\
\hline Intermittent & 400 & $8.64 \pm 0.72$ & $50.82 \pm 5.88$ & $342.15 \pm 16.31$ \\
\hline \multicolumn{5}{|l|}{ ANOVA } \\
\hline Lighting & & ns & ns & ns \\
\hline $\mathrm{AA}, \mathrm{mg} / \mathrm{l}$ & & $* * *$ & ns & * \\
\hline \multicolumn{2}{|c|}{$\frac{\text { Lighting } \times A A, m g / l}{a b \text { within rows means with different }}$} & $* * *$ & ns & $* * *$ \\
\hline \multicolumn{4}{|c|}{$\begin{array}{l}\text { The main and interactive effects of lighting and supplemental AA on mechanical characteristics of mid- } \\
\text { section of tibiotarsus }\end{array}$} & $\begin{array}{l}{ }^{* *} P<0.01, \quad{ }^{* *} P<0.001 \\
\text { haracteristics of mid- }\end{array}$ \\
\hline \multicolumn{5}{|c|}{$\begin{array}{l}\text { Die Haupt- und interaktiven Wirkungen von Beleuchtung und AA-Supplementation auf mechanische } \\
\text { Merkmale des Mittelabschnitts von Tibiotarsus (mean SEA) }\end{array}$} \\
\hline Lighting & $\mathrm{AA}, \mathrm{mg} / \mathrm{l}$ & Stress, MPa & Modulus of elasticity, MPa & Breaking force, $\mathrm{N}$ \\
\hline \multicolumn{5}{|l|}{ Main Effects } \\
\hline Continuous & & $104.46 \pm 8.21^{b}$ & $734.72 \pm 57.54^{b}$ & $521.95 \pm 18.25^{b}$ \\
\hline \multirow[t]{4}{*}{ Intermittent } & & $155.01 \pm 8.01^{\mathrm{a}}$ & $1138.74 \pm 57.88^{a}$ & $607.93 \pm 18.42^{a}$ \\
\hline & 0 & $125.89 \pm 9.92$ & $904.90 \pm 70.47$ & $558.85 \pm 22.35$ \\
\hline & 200 & $131.86 \pm 9.45$ & $959.38 \pm 70.21$ & $557.35 \pm 22.54$ \\
\hline & 400 & $131.45 \pm 9.26$ & $945.91 \pm 70.01$ & $578.62 \pm 22.85$ \\
\hline \multicolumn{5}{|l|}{ Interactive Effects } \\
\hline Continuous & 0 & $93.05 \pm 13.43$ & $673.02 \pm 99.66$ & $499.65 \pm 31.66$ \\
\hline Continuous & 200 & $93.84 \pm 13.81$ & $678.12 \pm 99.53$ & $470.80 \pm 31.58$ \\
\hline Continuous & 400 & $126.48 \pm 13.12$ & $853.01 \pm 99.09$ & $595.40 \pm 31.17$ \\
\hline Intermittent & 0 & $158.73 \pm 13.05$ & $1136.78 \pm 99.76$ & $618.05 \pm 31.55$ \\
\hline Intermittent & 200 & $169.89 \pm 13.56$ & $1240.64 \pm 99.44$ & $643.90 \pm 31.43$ \\
\hline Intermittent & 400 & $136.41 \pm 13.88$ & $1038.81 \pm 99.71$ & $561.85 \pm 31.16$ \\
\hline \multicolumn{5}{|l|}{ ANOVA } \\
\hline Lighting & & $* * *$ & $* * *$ & $* * *$ \\
\hline $\mathrm{AA}, \mathrm{mg} / \mathrm{l}$ & & ns & ns & ns \\
\hline Lighting $\times A A, m g / l$ & & * & ns & $* * *$ \\
\hline
\end{tabular}


Table 6

The main and interactive effects of lighting and supplemental AA on mechanical characteristics of distal section of tibiotarsus

Die Haupt- und interaktiven Wirkungen von Beleuchtung und AA-Supplementation auf mechanische Merkmale des distalen Abschnitts von Tibiotarsus (mean SEA)

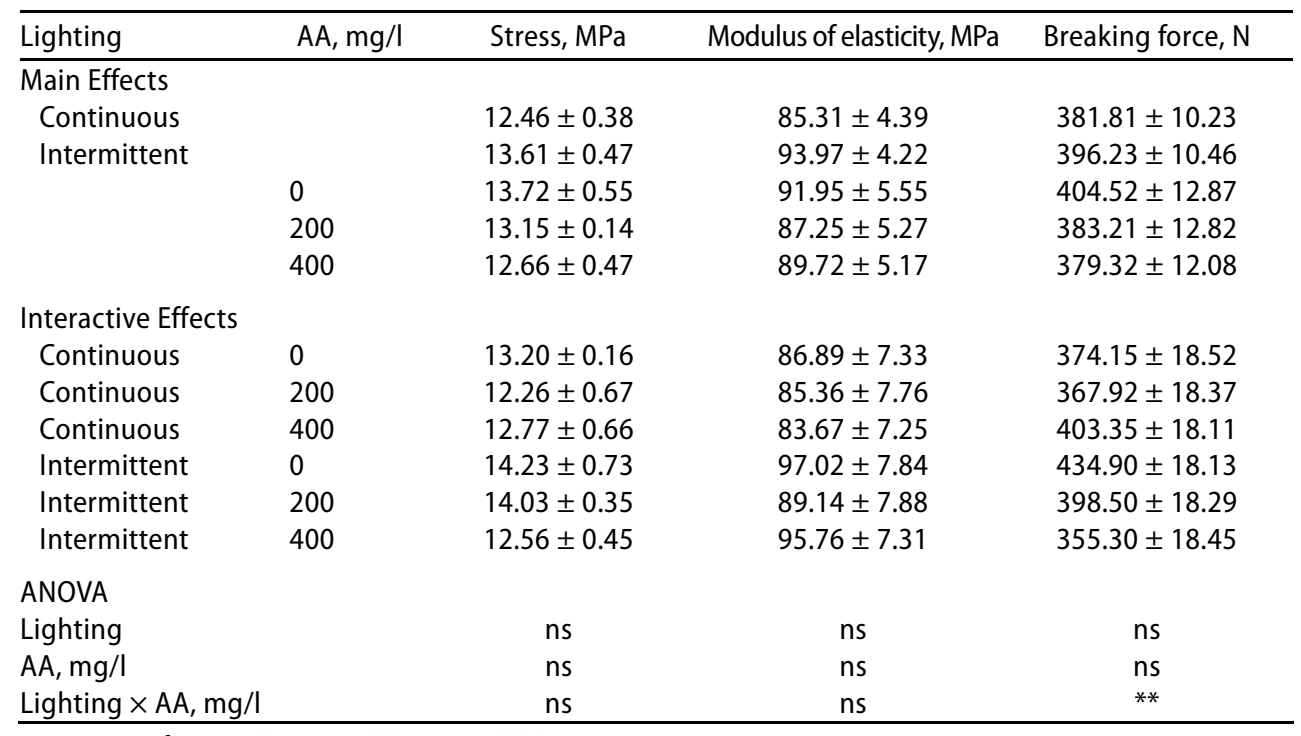

ns not significant, $\quad{ }^{*} P<0.05, \quad{ }^{*} P<0.01, \quad{ }^{* *} P<0.001$

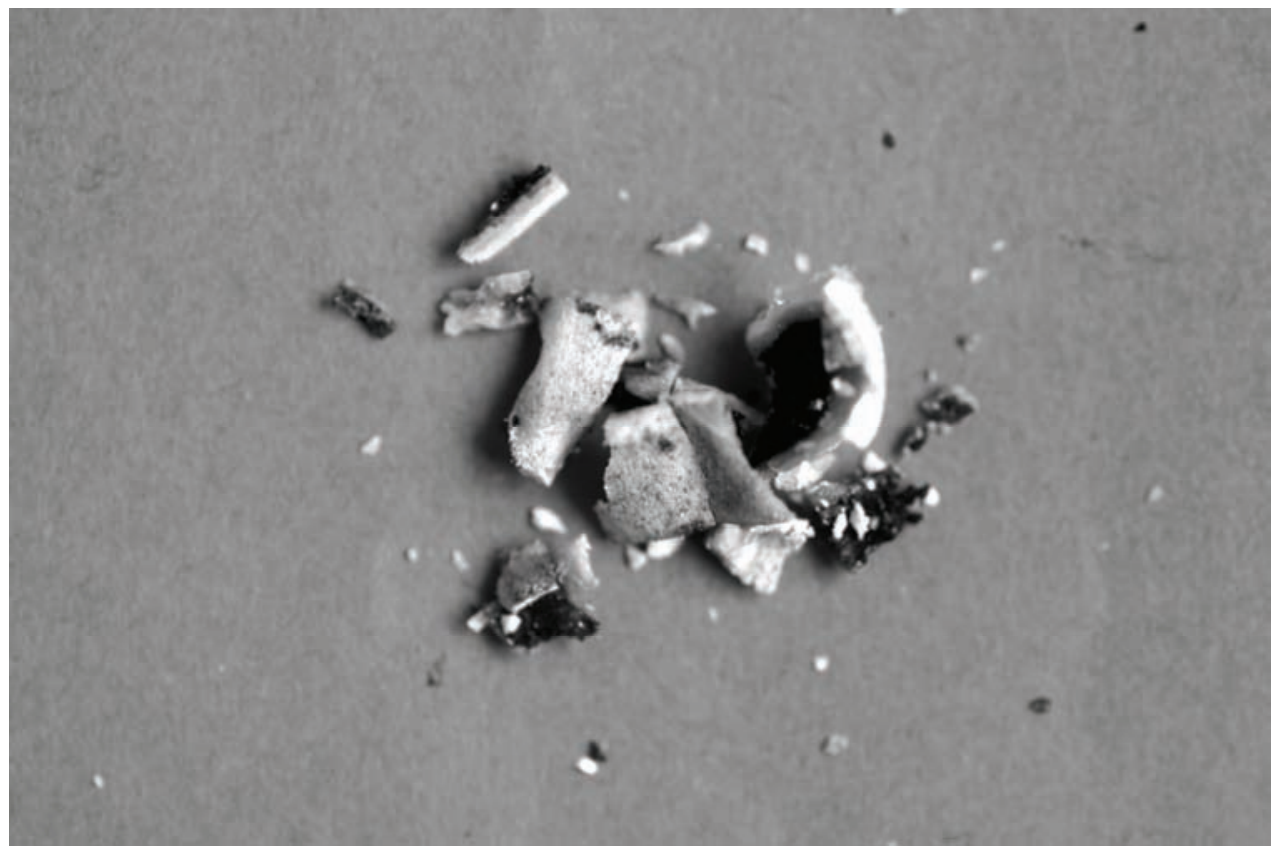

Figure 2

The type of breaking of the tibiotarsus mid section

Die Bruchart im mittleren Teil des Tibiotarsus 
Applied lighting programs had no significant effect on the proximal section of tibiotarsus whereas stress $(P<0.001)$ and breaking force $(P<0.05)$ were negatively affected by $A A$ supplementation. Likewise, stress and breaking force were influenced by the interactive effect of lighting and AA supplementation $(P<0.001)$. On the mid-section, while different AA supplementation had no significant influence, intermittent lighting positively affected $(P<0.001)$ the mechanical parameters of the bone (Figure 2). The interactive effect of lighting and $A A$ supplementation was found to affect the bone stress $(P<0.05)$ and breaking force $(P<0.001)$. Related to the distal section, although the main effects, lighting and $A A$ supplementation did not significantly affect mechanical parameters, interactive effect was only important on breaking force $(P<0.01)$.

\section{Discussion}

The effect of lighting and AA on serum and bone characteristics had already been studied by several researchers (BUCKLAND et al. 1976, NEWMAN and LEESON 1999, ONYANGO et al. 2003). In the present study, we have investigated the effect of different lighting schedule and $\mathrm{AA}$ on some serum and bone peculiarities in Ross $\mathrm{PM}_{3}$ broilers.

Body weight gain of broilers reared under intermittent lighting was better compared to other groups of animals $(P<0.05)$. The feed conversion ratio in intermittent lighting group was improved probably because of a shorter feeding period followed by a longer digestion period. Also other authors reports about the influence of intermittent lighting programs on growth performance (AL-MAHROUS 1997). Contrary to the findings obtained by DOAN and GIANG (1998), WHITEHEAD and KELLER (2003), and similar to those reported by PETEK et al. (2005) supplemental AA had no effect on body weight in broilers. Although in the present study we revealed that intermittent lighting had significant effect on the tibiotarsus weight $(P<0.05)$, some researchers failed to demonstrate this effect in their studies (INGRAM et al. 2000, PETEK et al. 2005). Increased body activity of the animals during intermittent period may be an explanation for the improved tibiotarsus weight. AA supplementation affected the weight of tibiotarsus in broilers; this is similar to those reported by EDWARDS (2000).

Contrary to the findings obtained by ELLIOT and EDWARDS (1997), LAN-XIA et al. (2006), in the present study serum ALP and Ca levels were increased with continuous lighting. Bone ash and Ca were also increased in continuous lighting group animals. This may be explained by considering the fact that animals reared under continuous lighting program would consume more feed and as a result of which their serum parameters would be higher. Moreover as stated before, lighting has positive effect on the bone mineral content (ELLIOT and EDWARDS 1997).

Contrary to the findings obtained by ORBAN et al. (1993), DOAN and GIANG (1998), SAHIN et al. (2002) and similar to those reported by SEYREK et al. (2004), LOHAKARE et al. (2005b), increased supplemental AA had no statistical effect on serum ALP and Ca in broilers. Similarly to DOAN and GIANG (1998) increased AA supplementation resulted with decreased serum $\mathrm{Pi}$ level $(P<0.001)$. On the other hand, bone ash, $\mathrm{Ca}$ and $\mathrm{P}$ levels augmented with increased $A A$ supplementation $(P<0.001)$. While these results are supported by the findings of ORBAN et al. (1993), DOAN and GIANG (1998), ONYANGO et al. (2003) and AFSHARMANESH and POURREZA (2005), they are not in concordance with 
those of reported by LOHAKARE et al. (2005b). Though serum Pi was decreased, there was no change in serum ALP and Ca values. Increased bone ash of tibiotarsus can be accepted as a positive indication for proper bone mineralization (AHMAD et al. 2000). Nonsignificant serum mineral values observed between the groups may be explained by the accumulation of minerals in the bones.

Lighting and AA supplementation interaction has additive effect especially on serum ALP. In chicks, ALP improved the bone development (YANEZ-RUIZ and MOLINA-ALCAIDE, 2008). In the present study the level of ALP was minimal in intermittent lighting and $200 \mathrm{mg} / \mathrm{l}$ AA supplementation group. This result supports the finding of LEBBIE and ADEMOSUN (1988) who point out that excess of serum ALP absorbed in the bones resulted in increased bone ash. Similarly, bone ash, $\mathrm{Ca}$ and $\mathrm{P}$ were almost highest levels in intermittent lighting and $200 \mathrm{mg} / \mathrm{I}$ AA supplementation interactive group. Increased level of melatonin and Vitamin D3 appeared during the dark phase of intermittent lighting group (INGRAM et al. 2000) would result in slowed growth of internal organs. In that case, the absorption of serum ALP, Ca and Pi in the bones would be triggered.

Tibiotarsus breaking force was not affected by lighting program (INGRAM et al. 2000, MCDONALD et al. 2001). CLASSEN et al. (1991) and PRAYITNO et al. (1997) respectively reported that intermittent lighting and continuous lighting programs positively affected the breaking force. In the present study we have found that lighting program has not effect on mechanical properties of proximal and distal section of tibiotarsus. However, mid-section was significantly $(P<0.001)$ affected by intermittent lighting. This may be dependent upon, as explained above, the increased blood melatonin level in intermittent lighting group resulting in development of bones particularly bone plaques in corpus region (INGRAM et al. 2000).

The AA had any effect on stress, modulus of elasticity and breaking force of tibiotarsus (NEWMAN and LEESON 1999, KOCABAGLI 2001, ONYANGO et al. 2003). Nonetheless, some researchers (ORBAN et al. 1993, DOAN and GIANG 1998, EDWARDS 2000, LOHAKARE et al. $2005 \mathrm{a}$, b) reported that tibiotarsus breaking force and modulus of elasticity were improved in birds fed with AA. In this study, AA has no influence on mechanical properties except stress and breaking force of proximal section of tibiotarsus. It has also negatively affected the bone stress and breaking force. These are contrast with the result reported by BURNELL et al. (1990), in which a linear increase in bone breaking force occurred when Ca was added into the diet.

The lighting and $A A$ supplementation is equally effective in bone development and breaking force (ELLIOT and EDWARDS 1997). In the present study, though the stress and breaking force of both proximal and mid section of tibiotarsus were affected by lighting and AA interaction, modulus of elasticity of the bone was not influenced from the employed factors. In distal section, only the breaking force was affected from this interaction. This divergence may be explained by the mechanical properties varying in each section of the bone and greater resorptive surface of trabecular structures especially found in mid-section. The use of AA in drinking water may result with different performance characteristics and biomechanical values. This could be due to the variable quantity of water drunk by each bird (FLEMING et al. 1998, NEWMAN and LEESON 1999, WHITEHEAD and KELLER 2003). 
Bone fractures in birds occur frequently in midshaft rather than epiphyseal region of leg bones (GREGORY and WILKINS 1989, FLEMING et al. 1998). For that reason corpus of the bone is the accurate part for evaluating bone breaking force (CRENSHAW et al. 1981, FLEMING et al. 1998). While high modulus elasticity can be accepted an indication for rigidity, low modulus can be for accepted for ductility (RATH et al. 2000). Moreover, it has been provided evidence that the percentage of bone ash is usually positively correlated with bone breaking force (WILSON 1991, ONYANGO et al. 2003). Finally, it can be concluded from the present study that intermittent lighting and $200 \mathrm{mg} / \mathrm{l}$ AA supplemented group that provided optimal results for mechanical characteristics and bone ash contents of tibiotarsus can be suggested as the best approaches for broiler breeding.

\section{Acknowledgements}

This study was supported with a grant from the Scientific and Technical Research Council of Turkey (TUBITAK, TOVAG-104V138). The authors thank Dr. Recep Cibik, Tülay Cibik and Dr. Veli Y. Cirak for their editorial assistance in the preparation of the manuscript.

\section{References}

Afsharmanesh M, Pourreza J (2005) Effect of calcium citric acid ascorbic acid vitamin $D_{3}$ on the efficiacy microbial phytase in broiler starters fed- wheat based diets. I. Performance, bone, mineralization, ileal digestibility. Int J Poultry Sci 4, 418-24

Ahmad T, Rasool S, Sarvar M, Haq A, Zia-UI H (2000) Effect of microbial phytase from a fungus aspergillus niger on bioavailability of phosphorus and calcium in broiler chickens. Anim Feed Sci Techn 83, 103-14

Al-Mahrous M (1997) Influence of age at the beginning of intermittent light program on the fattening performance of broilers. Arch Tierz 40, 159-64

Andrassy-Baka G, Romvari R, Milisits G, Suto Z, Szabo A, Locsmandi L, Horn P (2003) Non-invasive body composition measurement of broiler chickens between 4-18 weeks of age by computer tomography. Arch Tierz 46, 585-95

Anonymous (2003) Humane slaughter of poultry. California Poultry Slaughter Regulations. Michigan State University, article 15.1, 3 CCR 1245-13

Association of Official Agricultural Chemists (1955) Official Methods of Analysis. 8th ed, Washington DC, Method number 22.10

Buckland RB, Bernan DE, Goldrosen A (1976) Effect of four lighting regimes on broiler performance leg abnormalities and plasma corticoid levels. Poultry Sci 55, 1072-6

Burnell TW, Cromwell GL, Stahly TS (1990) Effects of particle size on the biological availability of calcium and phosphorus in defluorinated phosphate for chicks. Poultry Sci 69, 1110-7

Classen HL, Riddell C, Robinson FE (1991) Effects of increasing photoperiod length on performance and health of broilers. Brit Poultry Sci 32, 21-9

Coates ME (1984) Metabolic Role of the Vitamins in Physiology and Biochemistry of the Domestic Fowl. Academic Press London UK, 27-36

Crenshaw TD (1986) Reliability of dietary Ca and P and bone mineral contents as predictors of bone mechanical properties at various time periods in growing swine. J Nutr 116, 2155-70

Crenshaw TD, Peo ER, Lewis AJ, Moser BD (1981) Bone strength as a trait for assessing mineralization in swine; a critical rewiev of technics involved. J Anim Sci 53, 827-35

Doan BH, Giang VD (1998) Effects of vitamin C supplementation of a diet for 0-4 week old chicks on the absorption of calcium and phosphorus. Agricult Trop Subtrop 31, 117-21

Edwards HM (2000) Nutrition and skeletal problems in poultry. Poultry Sci 79, 1018-23

Elliott MA, Edwards HM (1997) Effect of genetic strain, calcium and feed withdrawal on growth, tibial dyschondroplasia, plasma 1,25 dihydroycholecalciferol, and plasma 25-hydroxycholecalciferol in sixteen-day-old chickens. Poultry Sci 73, 509-19 
Fleming RH, McCormack HA, Whitehead CC (1998) Bone structure and strength at different age in laying hens and effects of dietary particulate limestone vitamin $\mathrm{K}$ and ascorbic acid. Brit Poultry Sci 39, 434-40

Gericke S, Kurmies B (1952) The colorimetric determination of phosphoric acid with ammonium vanadate-molybdate and its application in plant analysis. Z Pflanzenernähr Bodenk 104, 235-47 [in German]

Gregory NG, Wilkins LJ (1989) Broken bones in domestic fowl handling and processing damage in endof-lay battery hens. Brit Poultry Sci 30, 555-62

Ingram DR, Hatten LF, McPherson BN (2000) Effects of light restriction on broiler performance and specific body structure measurements. J Appl Poultry Res 9, 501-4

Knowles TG, Wilkins LJ (1998) The problems of broken bones during handling of laying hens-a review Poultry Sci 77, 1798-802

Kocabagli N (2001) The effect of dietary phytase supplementation at different levels on tibial bone characteristics and strength in broilers. Turk J Vet Anim Sci 25, 797-802

Kutlu HR, FORBES JM (1993) Self-selection of ascorbic acid in colored foods by heat-stressed broiler chicks. Physiol Behav 53, 103-10

Lan-Xia Z, Zheng-Xiang S, Xin-Ying W, Ai-Lian G, Bao-Ming L (2006) Effects of ultraviolet radiation on skeleton development of broiler chickens. Agricult Sci China 5, 313-7

Laster CP, Hoerr FJ, Bilgili SF, Kincaid SA (1999) Effects of dietary roxarsone supplementation, lighting program, and season on the incidence of leg abnormalities in broiler chickens. Poultry Sci 78, 197-203

Lebbie SHB, Ademosun AA (1988) The effect of dietary calcium and phosphorus level on the performance of starter in the humid tropics. Bulletin Anim Health Prod Africa 36, 1-13

Lohakare JD, Ryu MH, Hahn TW, Lee JK, Chae BJ (2005a) Effects of supplemental ascorbic acid on the performance and immunity of commercial broilers. Poultry Sci 14, 10-9

Lohakare JD, Kim JK, Ryu MH, Hahn TW, Chae BJ (2005b) Effects of vitamin C and vitamin D interaction on the performance immunity and bone characteristics of commercial broilers. J Appl Poultry Res $14,670-8$

McDonald AL, Chen TC, Lott BD, May JD (2001) Component yields and tibia characteristics of broilers as affected by feed and light restriction. J Appl Anim Res 20, 1-14

McCorkle FM, Glick B (1980) The effect of ageing on immune competence in the chicken: Antibody mediated immunity. Poultry Sci 59, 669-72

Newman S, Leeson S (1999) The effect of dietary supplementation with 1,25-dihydroxycholecalciferol or vitamin C on the characteristics of the tibia of older laying hens. Poultry Sci 78, 85-90

Onyango EM, Hester PY, Stroshine R, Adeola O (2003) Bone densitometry as an indicator of percentage tibia ash in broiler chickens fed varying dietary calcium and phosphorus levels. Poultry Sci 82, 1787-91

Orban Jl, Roland DASR, Cummins K, Lovell RT (1993) Influence of large doses of ascorbic acid on performance plasma calcium bone characteristics and eggshell quality in broilers and leghorn hens. Poultry Sci 72, 691-700

Petek M, Sonmez G, Yildiz H, Baspinar H (2005) Effects of different managements factors on broiler performance and incidence of tibial dischondroplasia. Brit Poultry Sci 46, 16-21

Prayitno DS, Phillips CJC, Stokes DK (1997) The effects of color and intensity of light on behavior and leg disorders in broiler chickens. Poultry Sci 76, 1674-81

Rath NC, Huff GR, Huff WE, Balog JM (2000) Factors regulation bone maturity and strength in poultry. Poultry Sci 79, 1024-32

Sanotra GS, Lund JD, Ersboll AK, Petersen JS, Vestergaard KS (2001) Monitoring leg problems in broilers: A survey of commercial broiler production in Denmark. World's Poultry Sci J 57, 55-69

Seyrek K, Yenisey C, Serter M, Kargin Kiral F, Ulutas PA, Bardakcioglu HE (2004) Effects of dietary vitamin c supplementation of some serum biochemical parameters of laying japanese quails exposed to heat stress $\left(34.8^{\circ} \mathrm{C}\right)$. Rev Med Vet $155,339-42$

Snedecor GW, Cochran WG (1989) Statistical Methods, 8th ed, Ames lowa State University Press, USA

SPSS (1999) SPSS 10 Computer Software, Chicago, USA

Sahin K, Sahin N, Yaralioglu S (2002) Effects of vitamin C and vitamin E on lipid peroxidation blood serum metabolites and mineral concentrations of laying hens reared at high ambient temperature. Biol Trace Elem Res 85, 35-45

Wilson JH (1991) Bone strength of caged layers as affected by dietary calcium and phosphorus concentrations reconditioning and ash content. Brit Poultry Sci 32, 501-8

Whitehead CC, Keller T (2003) An update on ascorbic acid in poultry. World's Poultry Sci J 59, 161-84 
Yanez-Ruiz DR, Molina-Alcaide E (2008) A comparative study of nutrients utilization alkaline phosphatase activity and creatinine concentration in the serum of sheep and goats fed diets based on olive leaves. J Anim Physiol Anim Nutr 92, 41-148

Zubair AK, Leeson S (1996) Compensatory growth in the broiler chicken. World's Poultry Sci J 52, 189-201

Received 13 June 2008, accepted 3 March 2009.

Corresponding author:

Prof. Dr. HÜSEYIN YILDIZ

email: yildiz@uludag.edu.tr

Anatomi Anabilim Dali, Veteriner Fakultesi, Uludag Universitesi, 16059 Görükle-Bursa, Turkey 